\title{
Elephant in ancient Egypt (A Philological - Religious Study)
}

Enas Bahi ElDin Abdel Naiem

\section{Abstract:}

This article examines the presence of elephant in ancient Egyptian language to illustrate its different names, its ideograms and its rare representations in ancient Egyptian texts. As well its religious role depending on two elephant burials at Hierakonpolis in upper Egypt, several predynastic and archaic period depictions of elephant and a spell of coffin texts which back to the time of the middle kingdom.

\section{Introduction:}

Elephants are large mammals of the family Elephantidae and the order Proboscidea, from prehistoric period of ancient Egypt there are records of the presence of the African elephant (Loxodonta africana) on palettes, ivory carvings, painted ceramics, and rock paintings, as for the Asian elephant (Elephas maximus) became known in Egypt for the first time during the Near Eastern campaigns of the New Kingdom ${ }^{(1)}$, There are a few characteristics that distinguish the African from the Asian elephant, The African elephant is larger and has much larger ears, longer tusks, and is sway-backed, whereas in the Asian species the back arches upward. The forehead of the African species is lower and the crown of the head is without the two bumps that are characteristic of the Asian species. There are two 'fingers' on the tip of the trunk of the African, but only one on that of the Asian elephant ${ }^{(2)}$, these two species of elephants that we try to know its presence in ancient Egyptian language and its religious role.

\section{The Philological study:}

The word "elephant" is derived from the Latin elephas which is the latinised form of the Greek

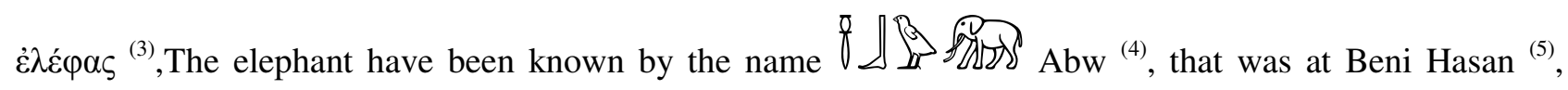
Elephant appears on the Pithom stela with the name

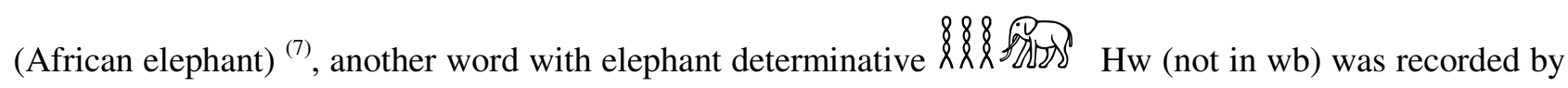
Fairman from the kiosk of Senusret I at Karnak he translated it ' grown elephant ' which is presumably a

${ }^{(1)}$ Störk, L." Elephants", in :The Oxford encyclopedia of ancient Egypt,Vol.I,Oxford University Press, Oxford ; New York, 2001, p.467.

(2) Osborn,D.J., \& osbornovà, J., The Mammals of ancient Egypt, The Natural History of Egypt IV, England, 1998, p.125.

(3) Liddell, H.G.\& Scott, R., A Greek-English Lexicon,Clarendon press,Oxford,p.532.

(4) $\mathrm{Wb} \mathrm{I}, 7,15$.

${ }^{(5)}$ LD Text II, p. 97.

(6) Urk II, 102,4.; this stela back to patlomy II and it is in egyptian museum now ( CG 22183) for more about this stela see: Naville,É., "La stèle de Pithom", Z ̈̈S 40 (1902-1903), pp.66-75.

(7) Spiegelberg,W., Demotica II, München,1928, p. 8. 


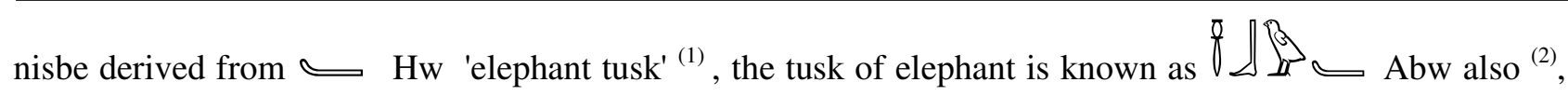
and elephant trunk as $\frown \operatorname{Drt}^{2} \mathrm{drt}^{(3)}$.

Elephants were depicted in the pre-dynastic rock drawings of Southern Upper Egypt from eastern and western desert wadis studied by Winkler ${ }^{(4)}$, but This sign the first ideogram of elephant we knew till till now in the ancient Egyptian language that used as determinative of the Elephantine town (modern Aswan) ${ }^{(5)}$, Vahala supposed that elephants must have survived this far south in Egypt when the town was named though it is also possible that the animals were named after the town, because of its connections with the ivory trade ${ }^{(6)}$, and Mercatante said that the island was called Elephantine because the rocks looked like elephants or because it was a depot for ivory trade ${ }^{(7)}$.

many representations of elephant are found only as the determinative of the Elephantine island such as the carving in the Dynasty 5 Causeway of Unas represents the hieroglyphic determinative for the description of red granite having been brought from Elephantine to build the Pyramid of Unas ${ }^{(8)}$, and in Palermo stone ${ }^{(9)}$, also the elephant head 15 is uesd as determinative in the name of Elephantine If 10 Abw ${ }^{(10)}$, elephant also appears as det. of Abw many times on the the rock tombs of the Princes of Elephantine from the time of the Middle Kingdom ${ }^{(11)}$, and on the Late Period (Dyn. 26) coffin of Ankhnesneferibrec(D26) ${ }^{(12)}$, the last ideogram of elephant appears in the word

(1) Fairman, H.W.," Notes on the Alphabetic Signs Employed in the Hieroglyphic Inscriptions of the Temple of Edfu", ASAE 43, 1943, p.284.

(2) $\mathrm{Wb} \mathrm{I}, 7,16$.

(3) $\mathrm{Wb} \mathrm{V}, 581,16$.

(4) Elephants represented in Winkler, H.A., Rock-drawings of Southern Upper Egypt,Vol.I , The Egypt exploration Society, London,1938, pl. 14,20,23,27 \& 28.

(5) Kahl,J., Frühägyptisches Wörterbuch,Vol.I, Harrassowitz Verlag, Wiesbaden, 2002, p.1.

(6) Vahala, F.," Der Elefant in Ägypten und Nubien", ZÄS 98, 1970, pp.81-83.

(7) Mercatante, A.S., Who's who in Egyptian mythology,New York,1978,p.42.; for more about name name of the Island of Elephantine see:

Platt, A. F. R.,"The origin of the name of the island of Elephantine", PSBA 30,1908, pp.206-207.;

Gauthier, H. , Dictionnaire des Noms Géographiques , Contenus dans les Textes Hiéroglyphiques ,vol.I. , Le Caire ,1925,p.3

(8) Osborn,D.J., \& osbornovà, J., op.cit., p.128.

(9) Urk I,245,3.

(10) Wb I, 7,18.

${ }^{(11)}$ Ex as: Müller, H. W., Die Felsengräber der Fürsten von Elephantine aus der Zeit des Mittleren Reiches, New York, 1940, p.109.

(12) Sander-Hansen, C. E., Die religiösen Texte auf dem Sarg der Anchnesneferibre, Kopenhagen, 1934, p.4.

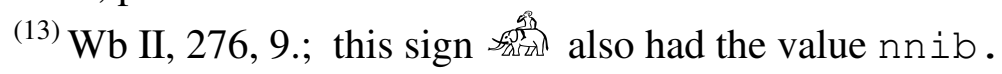


Elephant appeared in ancient Egyptian texts (but it is rare) through foreign tribute or military expeditions texts especially in the time of Thutmose I, Thutmose II , Thutmose III at Nija on the Orontes River $^{(1)}$, The most famous of these texts is the Biography of Amenemhab who accompanied Tuthmosis III when He hunted 120 elephants in Nija and the largest among them threatened the king life and Amenehab cut of its Drt (elephant s trunk) and saved Tuthmosis life, for which he received a gift of gold ${ }^{(2)}$.

\section{The religious role of elephant :}

The elephant lived all over Egypt during the Paleolithic and Neolithic as late as the Neolithic (Chalcolithic) period (4,000 B.C.), Several predynastic depictions of elephants are known from this time, They take the form of carvings on stone (petroglyphs) and ivory decorations and models on pottery and other $^{(3)}$, During Dynasties I (in the early third millennium BCE) increased desertification led to changes in the fauna, as aridity increased, the elephant disappeared from Egypt ${ }^{(4)}$, By dynastic times if not earlier, the elephant became extinct in Egypt, but deliberately interred remains of at least two African elephants in the Hierakonpolis locality (in human tombs) HK6 elite cemetery indicate that elephants could have a religious significance in this period ${ }^{(5)}$, an elephant god doubtlessly existed in the Predynastic as indicated from the statuette of a man with the head of an elephant (fig.1), which was discovered by Vercoutter (1959/1960) in a temple in Sudan (Wad Ban Naga) ${ }^{(6)}$, and in 1970 the German expedition of Musawwarat es Sufra at sudan discovered a graffito on the eastern outside wall of Temple 300, which appears to be an elephant-headed figure wearing a sun disk ( fig.2) The elephant god was worshipped in Meroïtic religion and this representation may be compared with the elephant statue at Wad Ban Naga and paralleled with the Indian god Ganeśa ${ }^{(7)}$, but in ancient egypt , there are no egyptian deitie take the elephant form, Despite of what Bonnet suggested that there are a connection among elephant and $\operatorname{Thot}^{\left({ }^{(8)}\right.}$.

on prehistoric objects handles of knives such as the knife-handles of the Brooklyn Museum ( fig.3) and the Pitt-Rivers collection ( fig.4 ) and Carnarvon-knife handle ( fig.5) and prehistoric ivory comb ( fig.6) , and a dynasty I gold mace handle (fig.7) the elephant represents trampling on snake ${ }^{(9)}$, this idea is mentioned also by classical authors who said that the motif of the battle between serpent and elephant, which

${ }^{(1)}$ Störk, L.,"Elefant", LÄ I, col.1214.; for more about this state see : Helck,W.,"Nija", LÄ IV, col.479-480.

${ }^{(2)}$ Breasted,J.H., Ancient Records of Egypt, vol.2, Univ. of Chicago Press,Chicago ,1906, p.233.;

for Thutmose II text see: Breasted,J.H., op.cit., p.233.; and Thutmose I see: Urk IV.104.

${ }^{(3)}$ Osborn,D.J., \& osbornovà, J., op.cit., pp.125-127.

(4) Lobban, A.R.,\& Liedekerke,V.,"Elephants in Ancient Egypt and Nubia", Anthrozoös 13, 2000,p.234.

(5) Friedman, R.,"Elephants at Hierakonpolis", in: Egypt at its origins : studies in memory of Barbara Adams, OLA 138, Peeters, Leuven, 2004, pp.131-168.

(6) Osborn,D.J., \& osbornovà, J., op.cit., p. 127.

(7) Hofmann,I.,"Eine neue Elefantengott-Darstellung aus dem Sudan", JEA 58,1972,pp. 245-246.

(8) Bonnet,H., Reallexikon der agyptischen Religionsgeschichte, Berlin,1952,p.113.

${ }^{(9)}$ Bénédite, G., "The Carnarvon ivory", JEA 5, 1918, pp. 225-241.; the prehistoric representations date from the Negade II culture . 
may be connected with Indian literature, Hofmann suggested that elephant and giant serpent here constitute a unit, Such a motif occurs in African myths, and it may be that it did also in the prehistoric Egyptian mythology, In Meroe there is found a possibly similar scene, but this motif came through the Physiologies in the Christian theology as the elephant (=Christ) and the Serpent (= Satan) ${ }^{(1)}$.

the symbolism of these figures is not known, but they may have been intended to destroy evil forces and provide the deceased with protection from snakes and during his journey in the netherworld ${ }^{(2)}$, We also find a confirmation of that idea in the texts of the coffins which back to the time of middle kingdom in spell
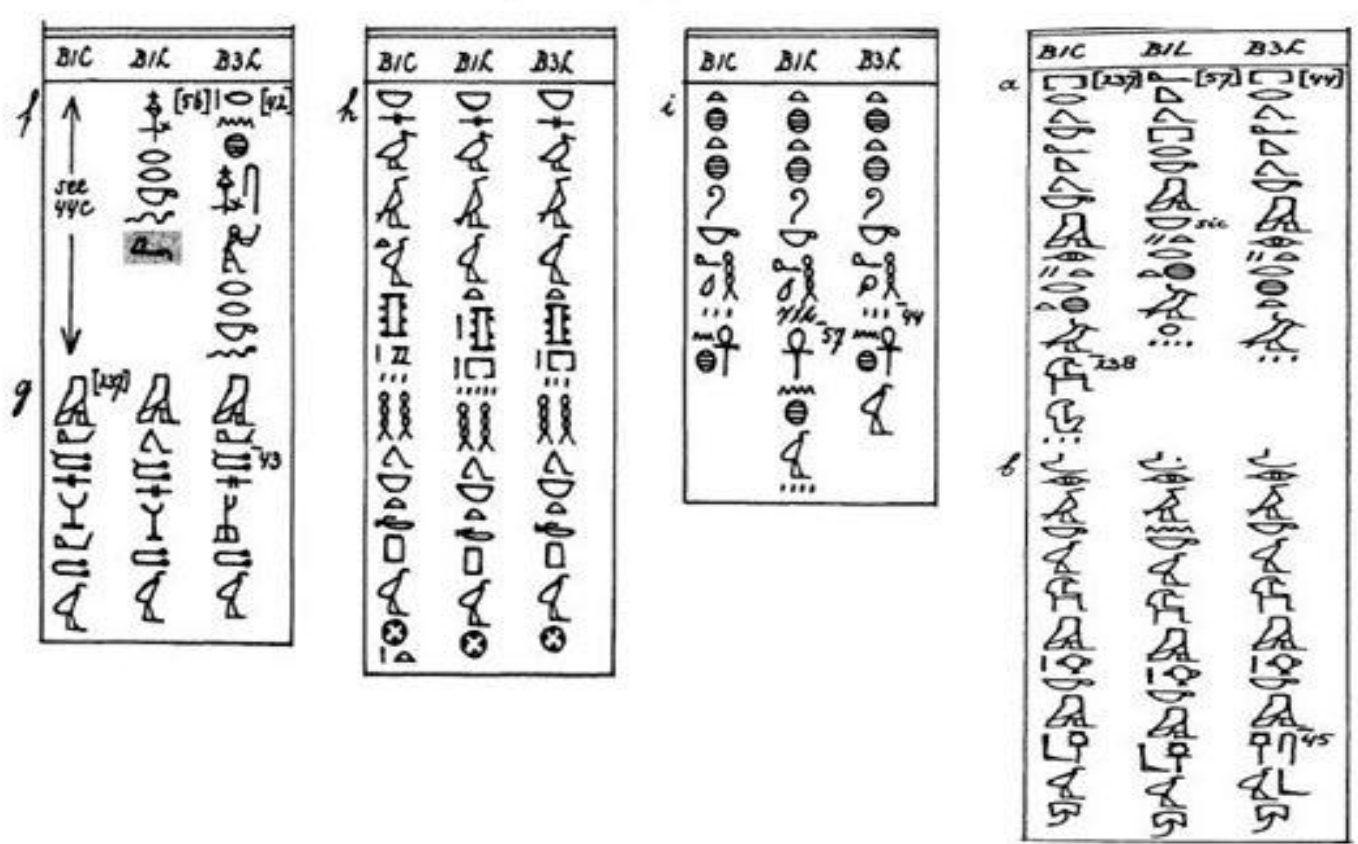

$379^{(3)}$.

R(A) n(y) xsf R(k)rk mi Tsi.Tw nb sAwt HHy nbt dp txtx.k Haw anxw pr.k aq.k m irty rxyt mAA.k wi m Hr.k m Abw.

To drive off Rerek-snake . Come, raise yourself, o Lord of walls (the deceased), seek out the Lady of Dep (Wadjet), stir up the living body, may you go out and go in in the eyes of rxyt-people, see me in front of you as an elephant .

This spell indicate to the desire of the deceased to be like an elephant to be able to see the Rereksnake ${ }^{(4)}$ during his journey in the netherworld as Osiris, but Unfortunately there is no religious text mentions the elephant to confirm the motif more and more except this spell ${ }^{(1)}$.

(1) Hofmann,I., " Zur Kombination von Elefant und Riesenschlange im Altertum", Anthropos 65, 1970, pp.619-632.

${ }^{(2)}$ Keimer, L., Histoires de serpents dans l'Égypte ancienne et moderne, cairo, 1947, p.25.

(3) CT V, 42f,g,h,i.\& 43a,b.

(4) for more about this serpent see:

ثناء جمعة محمود الرشيدى، الثعبان ومغز اه عند المصرى القديم من البدايات الأولى حتى نهايات الدولة الحديثة، رسالة دكتور اه،

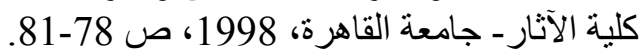




\section{Conclusion:}

- The word "elephant" is derived from the Latin elephas which is the latinised form of the Greek $\dot{\varepsilon} \lambda \dot{\varepsilon} \varphi \alpha \varsigma$.

- The elephant have been known in ancient Egyptian language by the name 8$]$ Abw,

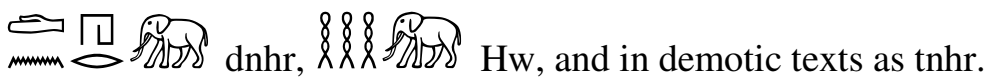

- All the ideograms of elephant and its parts in ancient Egyptian language are S.

- Elephant appeared in ancient Egyptian texts (but it is rare) through foreign tribute or military expeditions.

- Confirmation the religious significance of elephant in predynastic period in Egypt through two elephant burials at Hierakonpolis.

- There aren't any ancient Egyptian god take the elephant form but in Sudan an elephant god doubtlessly existed in the Predynastic period.

- the elephant represents trampling on snake on prehistoric objects handles of knives and this idea is mentioned also by classical authors may be indicate to destroy evil forces and provide the deceased with protection from snakes during his journey in the netherworld.

- There is no religious text has mentioned elephant except spell 379 in coffin texts which indicate to the desire of the deceased to be like an elephant to be able to see the Rerek- snake during his journey in the netherworld as Osiris .

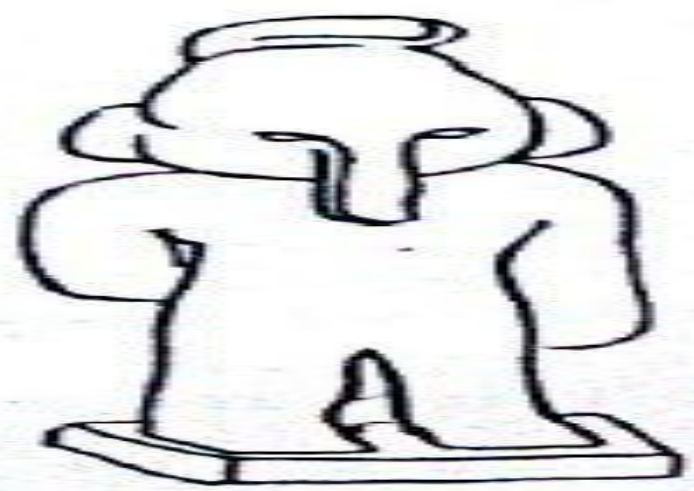

Fig.1: Drawing of a statuette of a predynastic elephant god from temple ruins in Wad Ban naqa(Naga), Sudan, 155 km N.E. of Khartoum.

(Source: Osborn,D.J., \& osbornovà, J., The Mammals of ancient Egypt, The Natural History of Egypt IV, England, 1998, p.129.)

(1) the elephant has been represented in religious texts but as determinative of the Elephantine for example in: pyr 234b. 


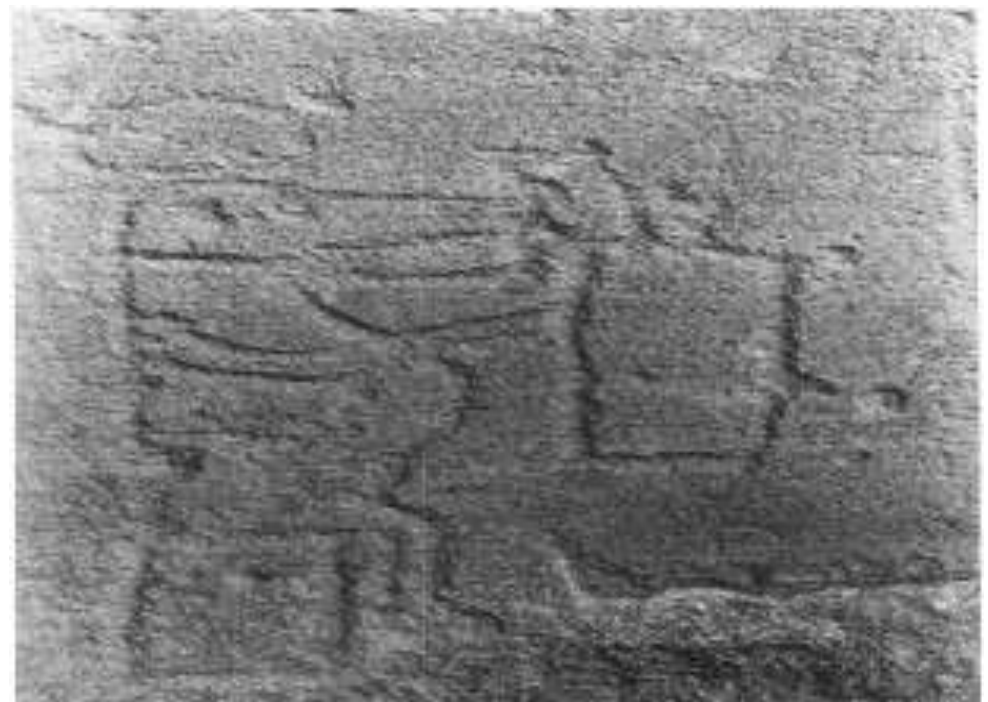

Fig.1: Graffito of elephant-headed figure wearing a sun disk from temple 300 (sudan).

(Source: Hofmann,I.,"Eine neue Elefantengott-Darstellung aus dem Sudan", JEA 58,1972,Pl. XLII.)

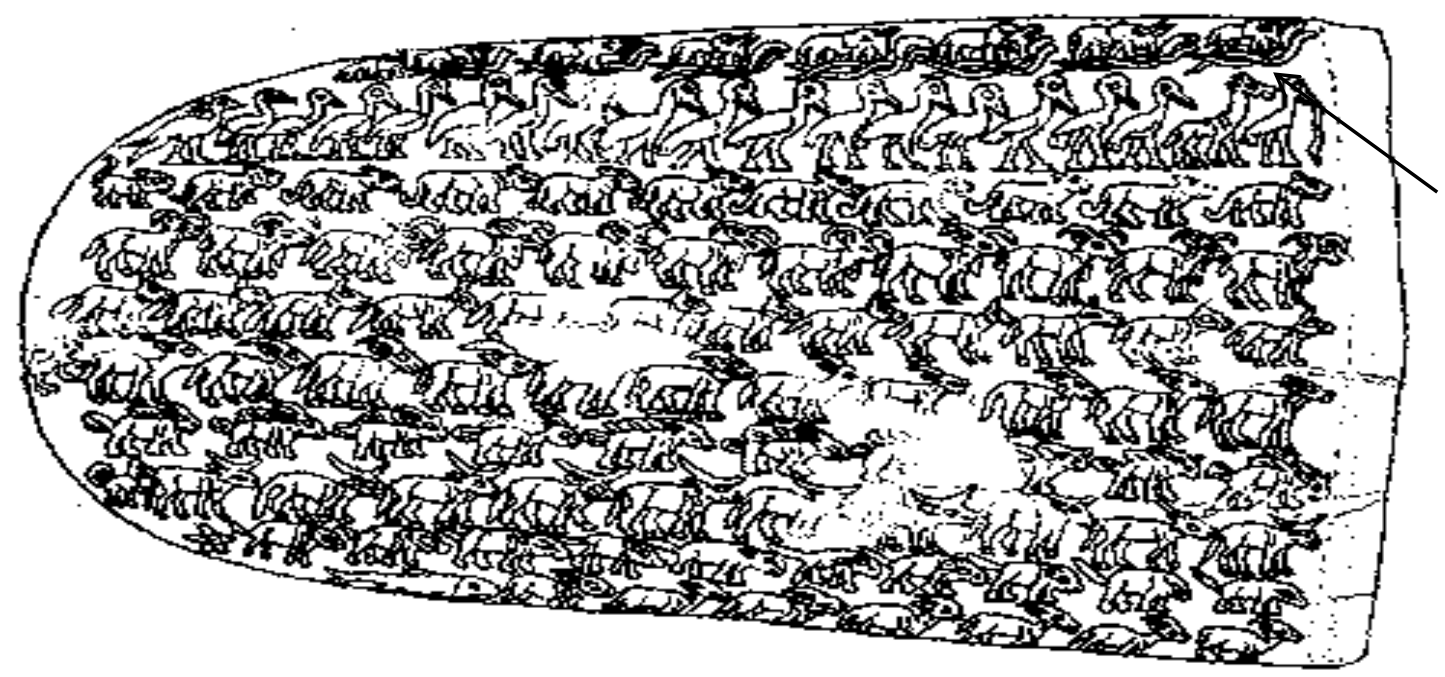

Fig.3: Obverse of the knife handle, in first row African Elephants trampling intertwined serpents.

(Source: Houlihan, P.F., The Animal World of the Pharaohs, London, p.41, fig.31.)

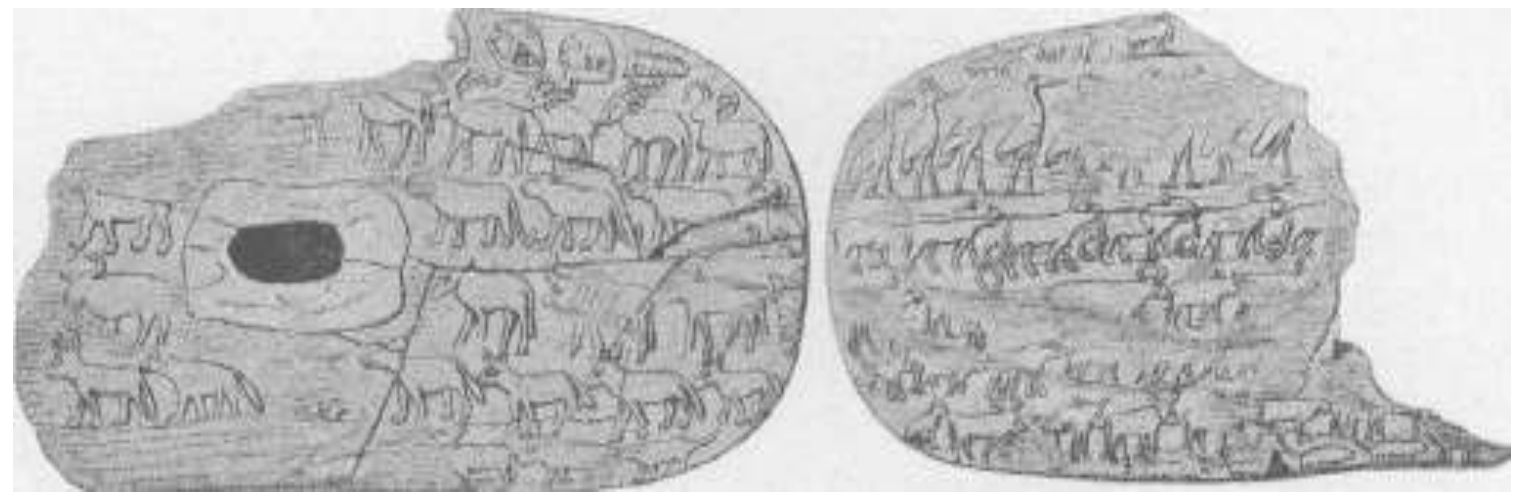

Fig.4: Ivory Knife-handle in the Pitt-Rivers Museum

(Source: Bénédite, G., "The Carnarvon ivory", JEA 5, 1918, p.227, fig.1.) 


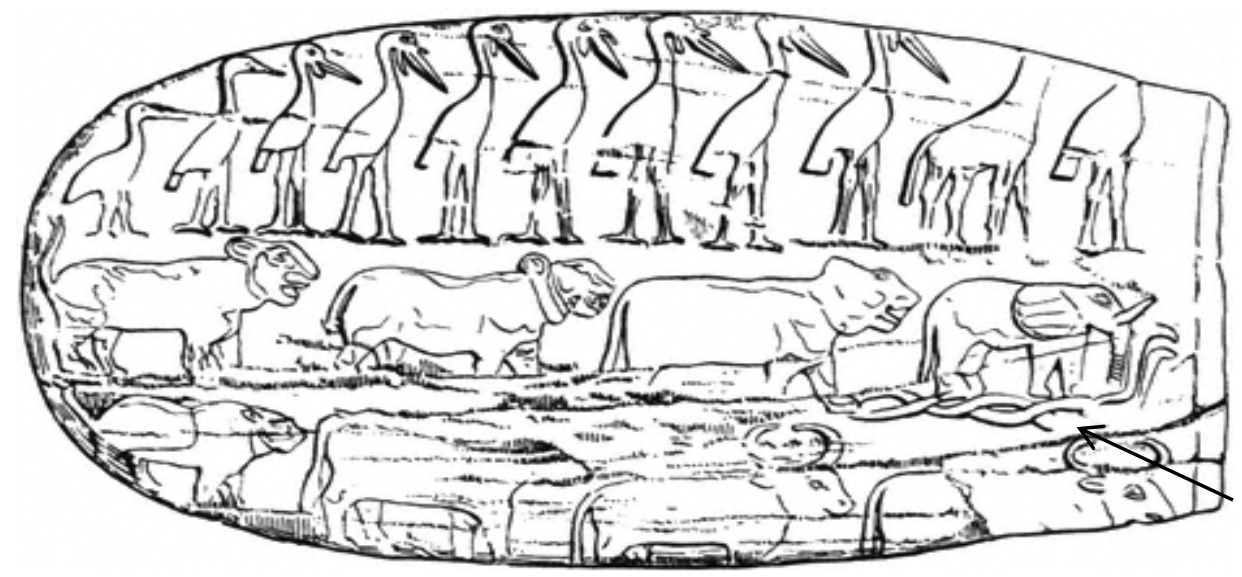

Fig.5: Carnarvon handle from late predynastic at the Metropolitan Museum of Art, New York.

(Source: Osborn, D.J., \& osbornovà, J., The Mammals of ancient Egypt, The Natural History of Egypt IV, England, 1998, p.6. )
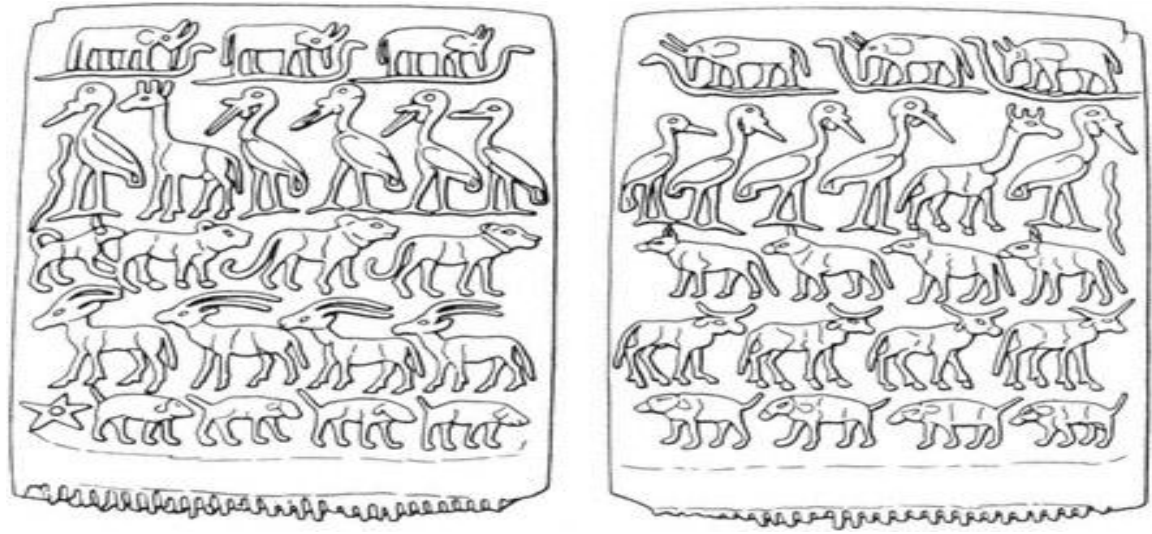

Fig.6: Elephants trampling on serpents in the top register of a prehistoric ivory comb.

(Source: Hofmann,I., " Zur Kombination von Elefant und Riesenschlange im Altertum", Anthropos 65,1970, p.621, Abb.2.)
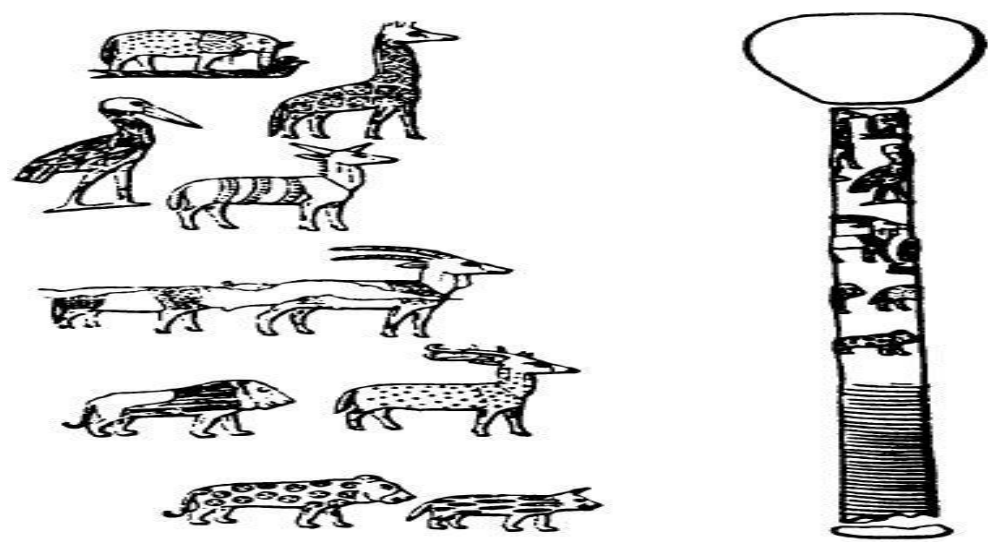

Fig.7: A dynasty I gold mace handle from Seiyala ruins west bank Nile in Nubia, at Egyptian museum.

(Source: Hofmann,I., " Zur Kombination von Elefant und Riesenschlange im Altertum", Anthropos 65,1970, p.621, Abb.3.) 
يتتاول هذا المقال وجود الفيل في اللغة المصرية القديمة لتوضيح أسمائه المختلفة و علاماته التصويرية وظهوره النادر فى النصوص التورئ المصرية

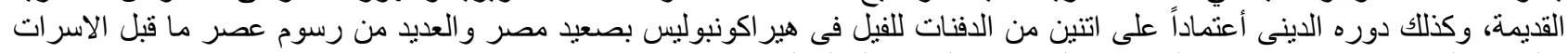

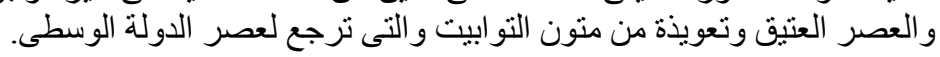

